\title{
Г.Г.Онищенко ${ }^{1}$ В.В.Малеев ${ }^{2}$, А.Г.Чучалин ${ }^{3}$, Е.Б.Ежлова ${ }^{1}$, Ю.В.Демина ${ }^{1}$, О.П.Курганова ${ }^{4}$, А.А.Перепелица ${ }^{4}$, И.И.Павлова ${ }^{4}$, Е.Н.Бурдинская ${ }^{5}$ \\ О ПРОФИЛАКТИЧЕСКИХ МЕРОПРИЯТИЯХ ПО СТАБИЛИЗАЦИИ ЗАБОЛЕВАЕМОСТИ ГРИППОМ, ОРВИ И ВНЕБОЛЬНИЧНЫМИ ПНЕВМОНИЯМИ В АМУРСКОЙ ОБЛАСТИ В ПОСТПАВОДКОВЫЙ ПЕРИОД
}

\begin{abstract}
${ }^{1}$ Федеральная служба по надзору в сфере защиты прав потребителей и благополучия человека, Москва, Российская Федерачия; ${ }^{2}$ ФБУН «Центральный научно-исследовательский институт эпидемиологии», Москва, Российская Федераиия; ${ }^{3}$ ГБУ «Научно-исследовательский институт пульмонологии» ФМБА России, Москва, Российская Федерачия; ${ }^{4}$ Управление Роспотребнадзора по Амурской области, Благовещенск, Российская Федерачия; ${ }^{5}$ ФУЗ «Центр гигиены и эпидемиологии в Амурской области», Благовещенск, Российская Федерачия
\end{abstract}

После масштабных чрезвычайных ситуаций на фоне хронического стресса предполагается закономерное снижение иммунитета, что может привести к осложнениям санитарно-эпидемиологической обстановки и способствовать росту заболеваемости ряда актуальных нозологических форм среди населения на пострадавших территориях. Проанализирована заболеваемость острыми респираторными вирусными инфекциями и внебольничными пневмониями в Амурской области в течение трехлетнего периода и дана оценка эпидемиологической ситуации в 2013 г. Внебольничные пневмонии остаются одной из ведущих причин заболеваемости, госпитализации и смертности в области и являются индикатором организации медицинской помощи населению. Заболеваемость внебольничными пневмониями в течение анализируемого периода регистрируется на высоком уровне, более чем в 2 раза превышающем показатель Российской Федерации и на 60-70 \% - по Дальневосточному федеральному округу.

В целях предупреждения распространения и формирования эпидемических очагов острых респираторных вирусных инфекций, гриппа и внебольничных пневмоний в Амурской области в постпаводковый период разработан комплекс санитарно-противоэпидемических (профилактических) и лечебных мероприятий, определены основные направления деятельности по стабилизации обстановки на перспективу.

Ключевые слова: чрезвычайная ситуация, острые респираторные вирусные инфекции, грипп, внебольничные пневмонии, эпидемиологический надзор.

\section{G.G.Onishchenko ${ }^{1}$, V.V.Maleev ${ }^{2}$, A.G.Chuchalin ${ }^{3}$, E.B.Ezhlova ${ }^{1}$, Yu.V.Demina ${ }^{1}$, O.P.Kurganova ${ }^{4}$,} A.A.Perepelitsa ${ }^{4}$, I.I.Pavlova ${ }^{4}$, E.N.Burdinskaya ${ }^{5}$

\section{Concerning Preventive Activities Providing Control over Morbidity Rates in Reference to Flue, ARVI, and Community-Acquired Pneumonia in the Amur Region in the Post-Flooding Period}

${ }^{I}$ Federal Service for Surveillance in the Sphere of Consumers Rights Protection and Human Welfare, Moscow, Russian Federation: ${ }^{2}$ Central Research Institute of Epidemiology, Moscow, Russian Federation: ${ }^{3}$ Research Institute of Pulmonology, Moscow, Russian Federation; ${ }^{4}$ Rospotrebnadzor Administration in the Amur Region, Blagoveshchensk, Russian Federation; ${ }^{5}$ Center of Hygiene and Epidemiology in the Amur Region, Blagoveshchensk, Russian Federation

It is supposed that after exposure to impacts of the large-scale high water on the background of chronic persistent stress, immune activity of the organism is decreased, which may lead to sanitary-epidemiological implications and contribute to morbidity rate increment as regards a number of relevant nosological entities among the population of the devastated territory. Statistically communityacquired pneumonias are still one of the key factors for infectious morbidity, hospitalization and mortality rate in the region. They are indicators for organization of medical assistance to the population. Therewith, evaluated has been morbidity rate in reference to acute respiratory viral infections and community-acquired pneumonias in the Amur Region for the past three years, assessed has been epidemiological situation throughout 2013.

Morbidity rate as regards community-acquired pneumonias in the Amur Region over the surveyed period (2010-2013) has turned out to be two times higher than the national one, and 60-70\% - than that throughout the Far Eastern Federal district.

In order to avoid distribution of the acute respiratory viral infections, flue, and community-acquired pneumonias and epidemic foci formation in the territory of the Amur Region in the post-flooding period, established is a complex of sanitary-anti-epidemic (prophylactic) and remedial measures. Besides of that, identified are the main areas of activities aimed at stabilization of the situation as a long term strategy.

Key words: emergency situation, acute respiratory viral infections, flue, community-acquired pneumonias, epidemiological surveillance.

Чрезвычайные ситуации различного характера способствуют формированию хронического стресса, закономерные последствия которого приводят к ослаблению неспецифической резистентности и снижению иммунологической защиты организма среди пострадавшего населения. В условиях наводнения, постигшего регионы Дальнего Востока России в летне-осенний период 2013 г., особую тревогу вызывают острые респираторные вирусные инфекции
(ОРВИ) и грипп, а также внебольничные пневмонии (ВП), часто формирующиеся на фоне обострения хронических соматических заболеваний и способные привести к значительным осложнениям эпидемиологической обстановки. ВП относятся к патологии с высоким уровнем летальности $[1,2]$. Кроме того, их можно расценивать как индикативные показатели качества медицинской помощи населению в регионе, в том числе направленные на профилактику развития 
осложнений при гриппе и ОРВИ.

Амурская область является одним из наиболее активных приграничных регионов, в которых культурно-экономические и хозяйственные связи тесно сопряжены с Китайской Народной Республикой (КНР). В соответствии с Концепцией внешнеэкономической деятельности Амурской области на 2011-2020 гг. ежегодное число выезжающих жителей региона в КНР составляет 60-90 тыс. чел., въезжающих граждан КНР - около 20 тыс. чел. Эпидемиологическая ситуация в регионе тесно связана с обстановкой на приграничных территориях, что требует особого подхода к организации санитарнокарантинных мероприятий на границе. В 2003 г. при регистрации случаев заболеваний людей высокопатогенным гриппом птиц в КНР принимались меры по запрещению въезда-выезда в Амурскую область в пункте пропуска «Благовещенск-пассажирский». В текущем году в ряде провинций Китая регистрировались случаи заболеваний людей гриппом А H7N9, число которых в декабре 2013 г. достигло 150, в том числе 47 - закончились летальным исходом.

Кроме того, Амурская область отличается от других территорий Дальнего Востока хорошей организацией медицинского обеспечения, связанного в том числе с наличием мощной учебной (ГБОУ ВПО «Амурская государственная медицинская академия») и специализированной (ФГБУ «Дальневосточный научный центр физиологии и патологии дыхания» РАМН) базы. Круглогодичный еженедельный мониторинг внебольничных пневмоний (ВП) в Российской Федерации введен Роспотребнадзором в условиях пандемии с ноября 2009 г. (письмо Роспотребнадзора от 14.11.2009 г. № 01/17159-9-32).

С учетом недостаточной этиологической расшифровки данной патологии $[2,3]$ диагноз «внебольничная пневмония〉 скрывает как известные инфекционные заболевания (легионеллез, орнитоз, лихорадка Ку, туляремия и другие), так и новые инфекции, вызванные ранее не известными возбудителями (тяжелый острый респираторный синдром, высокопатогенный грипп, ближневосточный респираторный синдром (коронавирусная инфекция). По данным формы 2 государственного статистического наблюдения, более $50,0 \%$ зарегистрированных внебольничных пневмоний остаются этиологически не расшифрованными.

Кроме того, имеются данные, что официальная статистика регистрации пневмоний (4-5 случаев на 1000 населения) значительно занижена, что является целью самостоятельного исследования. В Российской Федерации, по данным официальной статистики, ежегодно регистрируется около 500000 случаев пневмонии, хотя их предполагаемое число составляет около 1,5 млн [6]. ВП вызывают эпидемические очаги как в организованных коллективах, так и среди населения.

В последние годы Роспотребнадзором создана соответствующая нормативно-методическая база. Утверждены методические указания «Эпидемиологический надзор за внебольничными пневмониями» и «Лабораторная диагностика внебольничных пневмо- ний», которые определили основные подходы к проведению эпидемиологического надзора и организации профилактических мероприятий в очагах внебольничных пневмоний, тактику проведения этиологической расшифровки ВП. Утвержденные санитарноэпидемиологические правила «Профилактика внебольничных пневмоний» определяют стратегию по оптимизации эпидемиологического надзора и профилактики ВП на ближайшие годы и после регистрации в Минюсте будут введены (на начало декабря 2013 г. проходят регистрацию в Минюсте России) в действие. В адрес органов и организаций Роспотребнадзора для использования в практической деятельности направлен аналитический обзор «Внебольничные пневмонии: классификация, патогенез, этиология, эпидемиология, лабораторная диагностика на современном этапе» (от 01.11.2013 г.), подготовленный Нижегородским НИИЭМ Роспотребнадзора совместно с кафедрой пульмонологии Нижегородской медицинской академии.

В последние годы сезонный подъем заболеваемости гриппом и ОРВИ в Российской Федерации наблюдается в период с февраля по май. После перенесенной пандемии 2009 г. специалисты принимают дополнительные меры, направленные на повышение охвата иммунизацией против гриппа, которая в сезон 2013 г. началась с октября и достигла к декабрю 27,6 \% среди совокупного населения страны. С учетом прогнозов и риска роста заболеваемости гриппом, ОРВИ и ВП в Амурской области прививочная кампания началась еще в сентябре в период паводка, когда на подтопленных территориях было привито более 14 тыс. чел. В целом, охват вакцинацией против гриппа в Амурской области в 2013 г. превысил цифры по Российской Федерации и составил 34,4 \%. На начало 2014 г. в регионе привито более 282 тыс. чел., в том числе более 103 тыс. детей до 17 лет.

В структуре инфекционных и паразитарных болезней Амурской области ежегодно на долю гриппа и ОРВИ приходится от 80 до $90 \%$. К началу декабря 2013 г. эпидемиологическая ситуация в области характеризовалась как благополучная. Уровень инфекционной заболеваемости в целом по области ниже среднемноголетнего и не превышал среднемноголетних показателей. В сравнении с аналогичным периодом 2012 г. отмечалось снижение заболеваемости ОРВИ на 10,1 \%. За 11 мес. 2013 г. зарегистрировано 128627 случаев заболевания ОРВИ (15655,67 на 100 тыс. населения). Наибольший удельный вес среди заболевших составляли дети (возрастная когорта) дошкольных учреждений $-31,5 \%$ и школьники $30,1 \%$.

В ноябре 2013 г., по данным проводимого круглогодичного мониторинга циркуляции возбудителей гриппа и ОРВИ, в Амурской области заболевания гриппом не регистрировались. Отмечалась преимущественная циркуляция РС-вирусов - в $44,6 \%$, парагриппа 1, 2-го и 3-го типов - $37 \%$, аденовирусов - 17,3\%, на долю других респираторных вирусов (риновирусы) приходилось 1,2\% от числа 
обследованных больных. Планирование санитарнопротивоэпидемических (профилактических) мероприятий проводилось с учетом ретроспективного эпидемиологического анализа. По имеющимся данным, в эпидсезон 2011-2012 гг. в Амурской области заболеваемость гриппом была ниже среднемноголетнего показателя в 8,4 раза, ниже показателя заболеваемости по Российской Федерации (РФ) на 28,1 \% и ниже показателя по Дальневосточному Федеральному округу в 3 раза. Среди больных циркулировали вирусы гриппа типа В - 55,9\%, типа $\mathrm{A}(\mathrm{H} 1 \mathrm{~N} 1)$ и $\mathrm{A}(\mathrm{H} 3 \mathrm{~N} 2)-44,1 \%$.

В Амурской области так же, как и во всей стране, эпиднадзор за внебольничными пневмониями введен с ноября 2009 г. В соответствии с действующими нормативными методическими документами задачами эпиднадзора за ВП являются: постоянная и объективная оценка масштабов, характера распространенности и социально-экономической значимости инфекции; выявление тенденций эпидемического процесса; выявление районов, населенных пунктов и организаций с высоким уровнем заболеваемости и риском инфицирования; изучение этиологической структуры ВП; выявление контингентов, наиболее подверженных риску развития заболевания; выявление причин и условий, определяющих уровень и структуру заболеваемости ВП на территории; контроль и обоснованная оценка масштабов, качества и эффективности осуществляемых профилактических и противоэпидемических мероприятий; изучение и оценка результатов иммунизации населения против гриппа, пневмококковой и гемофильной инфекций; разработка периодических прогнозов эпидемиологической ситуации.

В последние 3 года показатели заболеваемости ВП в области регистрировались на высоких уровнях, более чем в 2 раза превышающих аналогичные показатели Российской Федерации и на 60-70 \% - показатели по Дальневосточному федеральному округу. Неблагополучие по заболеваемости ВП возможно отнести к объективным показателям с учетом постановки клинического диагноза на основе одного из самых доступных методов - рентгенологического, что обычно не вызывает затруднений. С другой стороны, хорошая выявляемость больных связана и с профессиональной подготовкой специалистов, немаловажную роль в которой играет ФГБУ «Дальневосточный научный центр физиологии и патологии дыхания». При анализе внутригодовой динамики заболеваемости внебольничными пневмониями установлено, что в течение года регистрируются 2 периода подъема заболеваемости: с января по апрель и с августа по октябрь. Рост заболеваемости в первый подъем начинается со 2-й календарной недели, с максимальным количеством зарегистрированных случаев на 4-7-й и 12-13-й неделях. Во второй подъем (август-октябрь) рост заболеваемости начинается с 34-й недели, с пиками регистрации случаев на 43-44-й неделях. Данная ситуация связана с ростом заболеваемости ОРВИ, формированием организованных коллективов.

В возрастной структуре наибольшее количество случаев зарегистрировано среди взрослых, на долю которых приходится 71,9\%, (РФ - 65,8 \%), дети до 17 лет составляют $28 \%$ (РФ - 34,4\%). Наибольший удельный вес заболеваемости пневмонией среди взрослого населения приходится на возрастную группу от 40 до 64 лет, что составило 44,6\% (по РФ - 48,8 \%). В 2013 г. среди детей заболеваемость чаще регистрировалась в возрастной группе от 0 до 2 лет, что составило $37,3 \%$, за аналогичный период прошлого года наибольший удельный вес среди заболевших детей приходился на возрастную группу от 3 до 6 лет $(30 \%)$. Среди детского населения за 11 мес. 2013 г., как и в предыдущие годы, наибольший удельный вес составляют: неорганизованные дети $-43,2 \%$, учащиеся школ $-35,5 \%$, посещающие дошкольные учреждения $-21,3 \%$.

Рассматривая распределение заболеваемости по возрастным группам в течение года, можно отметить, что при общем снижении заболеваемости ВП в летний период происходит уменьшение удельного веса заболевших детей в среднем на $10 \%$ с июня по август. Так, если в период с января по май и с октября по декабрь ежегодно удельный вес заболевших детей до 17 лет составляет от 27 до 32,2\% от совокупного населения, то в период летних каникул доля детей с диагнозами «внебольничная пневмония» снижается до 18-20\% от общего числа заболевших.

В 2013 г. в 92,2 \% случаев регистрировалась средняя степень тяжести заболевания, в 4,7 \% - тяжелая и $3,1 \%$ - легкая. В сравнении с аналогичными периодами 2012 и 2011 гг. уменьшилась доля тяжелых случаев (за 11 месяцев 2012 г. удельный вес тяжелых случаев составил 7,4\%, за 11 месяцев 2011 г. - 6,4\%).

В этиологической структуре, как и в РФ, преобладают ВП неустановленной этиологии - 69,8 \% (в РФ - $54 \%$ ), вызванные бактериальной микрофлорой - 29,6 \% (в РФ - $44 \%$ ), из них пневмококки выделены у 9,6 \% больных пневмонией (в РФ - 1,3\%). Пневмонии, вызванные вирусами, составляют всего $0,6 \%$ (РФ - 2,1\%). Низкий уровень этиологической расшифровки заболеваний гриппом, ОРВИ и ВП является проблемой для учреждений здравоохранения области, что связано с недостаточным материальнотехническим оснащением лабораторий медицинских организаций.

В целях предупреждения предполагаемого распространения ОРВИ, гриппа и внебольничных пневмоний, формированию эпидемических очагов на территории, подвергшейся наводнению совместно с министерством здравоохранения в Амурской области был разработан и проведен комплекс дополнительных санитарно-противоэпидемических (профилактических) мероприятий:

- организована работа штаба по профилактике ОРВИ, гриппа и ВП;

- создана дополнительная экспертная лечебнодиагностическая комиссия по заболеваниям инфекций нижних и верхних дыхательных путей, в состав которой вошли пульмонологи, педиатры, терапевты, рентгенологи, врачи-лаборанты; 
- разработана методика по доставке клинического материала от больных в лаборатории медицинских организаций и центр гигиены и эпидемиологии по межтерриториальному принципу;

- внедрены в работу МУ 3.1.2.3047-12 «Эпидемиологический надзор за внебольничными пневмониями», утвержденные Главным государственным санитарным врачом Российской Федерации;

- откорректирован и принят к реализации Комплексный план профилактических и противоэпидемических мероприятий по профилактике ОРВИ и гриппа на 2013-2017 гг., утвержденный распоряжением Губернатора Амурской области 25.09.2013 г. № 165P; издано постановление главного санитарного врача по Амурской области от 04.09.2013 г. № 9 «О подготовке к сезонному подъему заболеваемости острыми респираторными вирусными инфекциями и гриппом в Амурской области в 2013-2014 гг.» и от 06.09.2013 г. № 10 «О санитарно-противоэпидемических мероприятиях в период ликвидации последствий наводнения в Амурской области».

В целях стабилизации эпидемиологической ситуации по инфекциям верхних и нижних дыхательных путей в послепаводковый период в декабре 2013 г. совместно с ФГБУ «Дальневосточный научный центр физиологии и патологии дыхания» $\mathrm{PAMH,} \mathrm{главным}$ пульмонологом-терапевтом Минздрава России академиком РАМН А.Г.Чучалиным, экспертом Всемирной Организации Здравоохранения (ВО3) в области инфекционных болезней академиком РАМН В.В.Малеевым, органами и организациями Роспотребнадзора в Амурской области, Хабаровском крае и Еврейской автономной области, проведены краткосрочные семинары для врачей медицинских организаций и специалистов органов и организаций Роспотребнадзора по вопросам клиники, лечения, диагностики и профилактики инфекций верхних и нижних дыхательных путей.

Вцеляхобеспечениясанитарно-эпидемиологического благополучия по инфекциям верхних и нижних дыхательных путей на пострадавших от наводнения территориях определены следующие задачи: актуализация схем диагностики и лечения гриппа, ОРВИ и внебольничных пневмоний; внедрение современных подходов в практику лечения больных; обеспечение необходимого оснащения медицинских организаций, подготовка специалистов; принятие дополнительных мер по улучшению этиологической расшифровки ОРВИ, внебольничных пневмоний, внедрение в практику лабораторий медицинских организаций современных методов лабораторных исследований (ИФА, ПЦР, РИФ); принятие дополнительных мер по усилению санитарно-карантинного контроля в пунктах пропуска через государственную границу Российской Федерации в соответствии с Международными медико-санитарными правилами (ММСП-2005); укрепление приграничного сотрудничества в рамках Шанхайской Организации Сотрудничества (ШОС) и подписанного в ноябре 2013 г. Соглашения между санитарно-эпидемиологическими службами государств-членов ШОС о взаимном информирова- нии; оптимизация противоэпидемической работы, связанная с внедрением в повседневную деятельность новых нормативных методических документов по гриппу, ОРВИ и внебольничным пневмониям; организация взаимодействия с профильными научноисследовательскими институтами, включая вопросы практической и методической помощи в лечебном процессе, диагностике и подготовке специалистов.

\section{СПИСОК ЛИТЕРАТУРЫ}

1. Биличенко Т.Н., Чучалин А.Г., Сон И.М. Основные итоги развития специализированной медицинской помощи больным пульмонологического профиля на территории Российской Федерации за период 2004-2010 гг. Пульмонология. 2012; 3:5-16.

2. Комар С.И., Алякринская М.Д. Значение исследований показателей перекисного окисления липидов в конденсате выдыхаемого воздуха интубированных пациентов в диагностике вентилятор-ассоциированной пневмонии. Пульмонология. 2012; вентиля.

3. Синопальников А.И., Фесенко О.В., Тихонов Ю.Г., Дуганов В.К. Тяжелая внебольничная пневмония: этиологическая структура. Антибиотики и химиотерапия. 2001; 46(6):6-11.

4. Синопальников А.И., Зайцев А.А. «Трудная» пневмония. M.: $2010.56 \mathrm{c}$.

5. Чучалин А.Г., Синопальников А.И., Чернеховская Н.Е. Пневмония. М.: Экономика и информатика; 2002. 480 с.

6. Чучалин А.Г., Синопальников А.И., Страчунский Л.С., Козлов Р.С., Рачина С.А., Яковлев С.В. Внебольничная пневмония у взрослых: практические рекомендации по диагностике, лечению и профилактике. Клин. микробиол. антимикробиол. хиMomepan. 2006; 8:54-86.

\section{References}

1. Bilichenko T.N., Chuchalin A.G., Son I.M. [The main results of development of specialized medical care for pulmonologic patients in the territory of the Russian Federation in 2004-2010]. Pulmonologia. 2012; 3:5-16.

2. Komar S.I., Alyakrinskaya M.D. [Impact of examination of lipid peroxidation in the breathed out air condensate of the intubated patients, in the dioxidation in the breathed out air condensate of the intubated patients, in the di-
agnostics of ventilator-associater pneumonial. Pulmonologia. 2012; $1: 52-5$.
3. Sinopalnikov A.I., Fesenko O.V., Tikhonov Yu. G., Duganov V.K. [Severe community-acquired pneumonia:" etiological structure]. Antibiotiki $i$ Khimioterapia. 2001; 46(6):6-11.

56 4. Sinopalnikov A.I., Zaitsev A.A. ["Difficult" pneumonia]. M.: 2010 $56 \mathrm{p}$.

5. Chuchalin A.G., Sinopalnikov A.I., Chernekhovskaya N.E. [Pneumonia]. M.: Ekonomika i Informatika; 2002.480 p.

6. Chuchalin A.G., Sinopalnikov A.I., Struchunsky L.S., Kozlov R.S., Rachina S.A., Yakovlev S.V. [Community-acquired pneumonia in adults; practical recommendations for diagnostics, treatment and prophylaxis]. Klin Mikrobiol. Antimikrob. Chimoter. 2006; 8:54-86.

Authors:

Onishchenko G.G., Ezhlova E.B., Demina Yu.V. Federal Service for Surveillance in the Sphere of Consumers Rights Protection and Human Welfare. 18, Bld. 5 and 7, Vadkovsky Pereulok, Moscow, 127994, Russian Federation.

Maleev V.V. Central Research Institute of Epidemiology. 3a, Novogireevskaya St., Moscow, 111123, Russian Federation.

Chuchalin A.G. Research Institute of Pulmonology. 32, $11^{\text {th }}$ Parkovaya St., Moscow, 105077, Russian Federation.

Kurganova O.P., Perepelitsa A.A., Pavlova N.I. Rospotrebnadzor Administration in the Amur Region. 30, Pervomayskaya St., Blagoveshchensk, 675002, Russian Federation.E-mail: info@rospotrebnadzor-amur.ru

Burdinskaya E.N. Center of Hygiene and Epidemiology in the Amur Region. 30, Pervomayskaya St., Blagoveshchensk, 675002, Russian Federation. E-mail: office@cge-amur.ru

Об авторах:

Онищенко Г.Г., Ежлова Е.Б., Демина Ю.В. Федеральная служба по надзору в сфере зашиты прав потребителей и благополучия человека. Российская Федерация, 127994, Москва, Вадковский переулок, дом 18, строение 5 и 7.

Малеев В.В. Центральный научно-исследовательский институт эпидемиологии. Российская Федерация, 111123, Москва, ул. Новогиреевская, 3а.

Чучалин А.Г. Научно-исследовательский институт пульмонологии. Российская Федерация, 105077, Москва, ул. 11-я Парковая, 32. E-mail pulmo_fmba@mail.ru

Курганова О.П., Перепелица А.А., Павлова И.И. Управление Роспотребнадзора по Амурской области. Российская Федерация, 675002, Благовещенск, ул. Первомайская, 30. E-mail: info@rospotrebnadzor-amur.ru Бурдинская Е.Н. Центр гигиены и эпидемиологии в Амурской области. Российская Федерация, 675002, Благовещенск, ул. Первомайская, 30. E-mail: office@cge-amur.ru 